

\section{Sustainable Development of Fragile Mountain Areas of Asia}

\section{Regional Conference Report}

\section{Edited by}

Mahesh Banskota

Archana S. Karki

International Centre for Integrated Mountain Development Kathmandu, Nepal 


\section{Copyright (C) 1995}

\section{International Centre for Integrated Mountain Development}

\section{All rights reserved}

Published by

International Centre for Integrated Mountain Development

G.P.O. Box 3226 ,

Kathmandu, Nepal

\section{ISBN 92-9115-371-0}

Typesetting at ICIMOD Publications' Unit

The views and interpretations in this paper are those of the author(s). They are not attributable to the International Centre for integrated Mountain Development (ICIMOD) and do not imply the expression of any opinion concerning the legal status of any country, terntory. city or area of its authorities, or concerning the delimitation of its frontiers or boundaries. 


\section{FOREWORD}

Although ICIMOD's activities focus primarily on the Hindu Kush-Himalayas, the Centre's motto is to think globally and act regionally. It is this approach that motivated ICIMOD to accept the request of $F A O$ (the UN focal point for Chapter 13 of Agenda 21) to organise this first-ever meeting on the mountain areas of Asia. The response from the Asian countries has been most enthusiastic and demonstrated a unanimous concern among the Asian countries regarding the deteriorating livelihoods of mountain people and the quality of their environments, in spite of the high variations among the mountain areas of Asia.

Mountain areas in many Asian countries represent extremely vital natural environ ments determining local climates, regulating downstream hydrology, providing biological diversity, and being a home for culturally rich and vibrant mountain communities. Unfortunately, development in mountain areas so far has not been friendly either to the mountain people or to their environment and this must change in a very fundamental way in the future.

The most significant achievement of the Conference, apart from the wide sharing of knowledge and experience in mountain development problems and opportunities, was the formulation of the Sustainable Development of Mountain Areas of Asia, or SUDEMAA, Call to Action recommendations. This in my opinion provides a timely beginning for all concerned to overcome centuries of neglect, isolation, and marginalisation of mountain peoples and the mountain environment.

Chapter 13 of Agenda 21 has started the process for sustainable development of fragile mountain areas. This Conference has hopefully taken it a step further by calling on nations concerned to put mountain agenda higher up on their respective national development agendas. If ICIMOD can help promote this effort further, as request ed by many of the participating countries, it is keen to help in any way it can.

I would like to express my sincere gratitude to the Rt. Honourable Prime Minister of Nepal, Mr. Man Mohan Adhikari, the Assistant Director General of FAO, Mr. A.Z.M. Obaidullah Khan, Ms. Savitri Kunadi, Vice-Chairperson of the UN Commission for Sustainable Development, the representatives of the participating countries, and the resource persons for their valuable contributions to the Regional Conference. I also thank the Swiss Development Cooperation, FAO, UNDP, UNEP, and the UNU for their valuable support to the Conference. Lastly, I would also like to express my sincere appreciation to Dr. Mahesh Banskota, the Coordinator of the Workshop, and to all the other ICIMOD staff who have put in long hours of hard work both before and after the Conference, including the publication of this Conference Report. 


\section{Table of Contents}

Introduction

Setting the Scene: The Inauguration

Critical Issues: The Main Discussion

Looking Ahead with Agenda 21: Summary Country Statements

The SUDEMAA Call to Action

Field Visit to Dhaireni Rehabilitation Site, Kavrepalanchok District 